\title{
Freedom's Just Another Word / For Nothin' Left to Close / Desire Constructing Desire Constructing in Gail Scott's Heroine
}

\author{
Nicole Markotic
}

\begin{abstract}
Du désir entraînant du désir entraînant
Comment créer une héroüne qui ne sort pas du lieu du crime, qui reconnaît le rôle d'héroïnes du passé mais qui ne se soumet tout de même pas à la tradition de la victime ou de la future mariée, telle est la question centrale posée par Héroïne. Le roman de Scott s'oppose aux fins traditionelles. Ici, le personnage n'est pas un individu dont l'autoréalisation passe par la résolution de divers conflits dans l'action, mais plutôt par un processus arrosé du désir, se déroulant au grédu récit. S'éclaboussant de plaisir dans son bain, paysages et bruits urbains sous sa fenêtre, l'héroïne de Scott s'écrit - mais dans l'eau bien plus que dans l'encre. C'est seulement après avoir produit un scénario alternatif pour elle-même qu' elle est capable de sortir de son bain pour se promener dans les rues de Montréal - en effet, pour commencer son histoire.
\end{abstract}

There's a limit to female desire.

A story repeated so often we sometimes forget not to believe it: those Classical offerings of the fleeing maiden and the pursuant young man. That female desire might stretch beyond the traditional possibility of being "caught" (in either death or marriage) is still a radical alternative in literature.

The central question posed by Gail Scott's novel Heroine is how to create a "heroine" who doesn't exit the scene of the crime, who acknowledges the role of past heroines yet doesn't submit to the tradition of either victim or bride-to-be. And the off-centre achievement around which Scott develops her novel is a writing against that oh-so-central ideal of goal or end-climax within the Bildungsroman structure of selfbetterment. The heroine, splashing and pleasuring in her tub, is not aiming for the "final goal" of writing her novel. She is, albeit in water rather than ink, writing her self. This novel is not about the development of character through plot and closure, but rather about the importance of character-in-process and the telling of self. 
The heroine of Heroine is able to rise out of her bathtub and stroll into the Montreal morning only once she has written that character-inprocess script for the heroine of her novel. A process that develops out of the narrator's memories of a painful love affair, the collage of noise and sights outside her window, the visit from Marie, and the narrator's own sexual gratification. Around and around the narrative spirals, questing its own (pleasure) centre. Questing the location of subject: how not to write woman only as object. And when she has finally made up the words which mirror a reflection of her own character, the narrator does not "end" her book, but begins.

The first section of the ending is titled, "Jealousy, A Fish Story" (173). Scott ironically twists the happily-ever-after of, A Love Story. Heroine, although it covers the ground and the battle of love, is not a love story to end predictably in death or marriage. "Story," concerning women, is too often confused with a moralizing content, and "has typically meant plots of seduction, courtship, the energies of quest deflected into sexual downfall, the choice of a marriage partner, the melodramas of beginning, middle, and end, the trajectories of sexual arousal and release" (DuPlessis 151). The content of Heroine is a woman taking a bath and masturbating. Her "quest" is to do it until she is able to begin her own text. "If 'happily ever after' means anything, it means that pleasurable illusion of stasis" (DuPlessis 178). The narrator, at the same time as she is indulging her heroine in her illusion of stasis, is propelling that character forward in the text, forward to the list of possibilities that take up the last page.

Scott sets up the narrator, "Gail," who desires to write a novel about a heroine. She begins this quest in the bathroom, the most private and personal of rooms. Then she leaves the door open. This ambiguity of intention is set from the beginning of the novel. The first word we read, after the title, is "Sir" (Scott 9), a word of power signifying patriarchy. Immediately, that single utterance is undercut: by the halting English a petty authority figure speaks, and by the obvious incongruity and lack of power of the "Black tourist" (9) addressed. Nearly every section in the book begins with a sentence or paragraph about this tourist or with remarks about a grey woman who is a silent outcast of the Montreal streets. This narrative device opens up the possibilities of duality: heroine writing heroine, the heterosexual and the homosexual, memory and rebirth. Yet at the same time it offers more than a mere either/or binary. The narrator constructs herself from these layers: she refuses to settle for 
one single expression of her sexuality, she employs her memory for the purpose of rebirth, she writes that rebirth on top of memory. "Yes, she's pleased at how she's learning to write over the top of things. Whatever that means" (140-41). Her body has become the story, immersed in water, she writes over: a palimpsest version of her self she must write again and again and again to get it right. Not as an undoing, but a doing more. She dives into her bathtub in order to emerge whole and free and clean. She gets naked to avoid clothure. She doubles the ending to pleasure it into existence, into beginning. She masturbates and masturbates and masturbates her body into the text. She creates against finality, until that first "Sir" has metamorphosed into the final "She-" (183). The book comes to an end, but the possibility of the text continues.

The distance between the words in her head and the words on the page is a measure of the heroine's fiction - "I'm lying with my legs up" (9) - the space she creates so that she can step out and look back at the opening. "But I can't just sit down and write a novel about X. It all happens in the process of writing" (Scott, Spaces Like Stairs 81). So her novel becomes less about " $X$ " the heroine, than about the process of writing that heroine into existence. Of writing that creates writing.

"Lying with my legs up I see the whole picture in my head. As infinite as unsullied snow" (20). Scott's heroine strives to translate that picture into written words, as does the narrator of Lives of Girls and Women (who also attempts to write her self and her desire into the text). Del says, "I wrote out a few bits of it and put them away, but soon I saw that it was a mistake to try to write anything down; what I wrote down might flaw the beauty and wholeness of the novel in my mind" (Munro 203). Whereas Del doesn't want to spoil the perfection in her head by writing the words down, Gail doesn't want to limit the infinite with definition. In order to create herself as subject, though, she needs to create the idea of novel. "Putting one word ahead of another on the page gives a feeling of moving forward. I started thinking of the novel I would do" (21). She lounges in the bathtub, site of luxury and routine, and tells herself stories. Again and again and again. The narrative spirals inwards and outwards - retelling, detailing, expanding, contradicting. This narrator doesn't desire completion, she doesn't desire ending. She desires desire, and its lack of imposed borders.

"If I were to start a novel what would be the opening? Quick, free associate. A shrimp in the labia" (78). Where did that come from? she wonders, yet the image is not so far removed from the actual opening of 
the novel. A woman with her legs up, pleasuring herself with tap water: "Oh froth, your warm faucet's spurting warmly over my uh small point" (36). Once in that position, perhaps she is able to remove the "shrimp" from her labia. Who needs a penis when gushing frothy water will do as well? The narrator, creating the text inside her head, is writing the lover out of existence as she writes herself in. The concluding sentence of Audrey Thomas' Latakia suggests that the "best revenge is writing well" (Thomas 172). But for Scott, who does not wish to end, merely, on a note of revenge, who does not wish to end at all, the revelation is in the writing itself. How to create a female subject when woman has previously been written as object? Scott rejects the final climactic movement, opting instead for the open-ended process of writing the feminine sexual self. The novel opens, not in media res because in a sense the entire novel is in media res, but post-coitus in that the narrator is already sunk into the "enamel embrace" (9) of the bathtub, already masturbating, continuing a series of orgasms whose origins trace back to before the first page. And the denouement is changed into a second ending; a second, or further, coming.

The shortest section of the book, the "middle" of the novel, is titled: "(I was a Poet before I was You)" (73). The parentheses because the narrator's sense of self has been subverted by her desire to please (to the extent that she wishes to become) her lover; because the heroine has only halfcompleted her articulation of her written/writing self. That this section stands by itself is a mark of its importance in the narrator's ongoing struggle to construct herself as heroine for the novel she attempts, in the bathtub, to script. Lying in still water, she is not only recalling a former lover, she is recalling a former self that exists under the layer of her obsession with Jon. Dreaming herself up as heroine, the narrator slips through the cracks of plot to reclaim her sense of language as poetry, to declare herself a writer of her own text, to give herself permission to follow wherever the poetics of narration meander.

The poet's role is to break rules, the heroine's is to adhere to rules. Janis Joplin, embodying both, belts out her pain, frustration, and passion. Her lyrics describe the book's framing device. "It's all the same goddamned day" (180), she sings. The narrator compresses her past ten years into this single day in the tub. Joplin represents the heroine who has not remained within the boundaries outlined for the conventional "feminine" heroine. Nor limits herself to one, stationary, state of being. The narrator, who is constantly being defined as one stereotype or 
another (an Anglo to the surrealist poets, merely female to the revolutionaries, too het for the lesbians), desires to achieve a construction of herself as composite being. She begins by writing multiplicity: a minor francophone authority figure offers, in halting English, instructions to a "Black tourist" who walks the city, on foot and through a telescope. The city presents to him sky scrapers and bagel shops, a field of car wrecks and a mountain with a cross on top. And a grey woman who "sits silently" (100) throughout the text, on cold park benches, on cement steps in front of busy cafes or rundown motels. The narrator's body remains in the bathtub, but she observes the city around her through one window. "In the telescope" (36), an observing eye notices the grey woman. She appears in the text often but not for much space. A complex character too minor to be heroine, and too recurring to be ignored. "The lens shift again" (95), so the focus on the woman blurs into grey as the camera eye of the narrative shifts back onto its heroine.

The narrator constantly strives to fashion a heroine suitable for the ideal text she desires. That heroine is a vision of herself that she needs to make up in order to read the version of self she so desires. "The woman's body is, so to speak, no longer a blank page but a written one-one which can even read" (Lenk 53). The narrator, in stripping down to her skin, deliberately flaunts her body to herself, self-consciously bathes while she washes the shaping imprint of the years out of her skin and into her self-constructing memory. She is not ridding herself of dirt and waste, she is making the discarded into fiction, transforming debris into poetry. Her determined ablutions are about ritually washing away the romantic and restricting definitions of "heroine" that she has had to confront in her attempts at a more genuine model. "The speaking body of feminine writing is perhaps (like the silent muse) only the condition of possibility for the birth of something other" (Morris 66). Scott creates setting within the "frame" of the bathtub, making it the site of both pleasure and pain. This fusing together of "sexual pleasure and ideological and personal loss" (Blumberg 64) explodes (again and again and again) in sexual tension and creative energy. In order to construct the ideal heroine, the narrator must first scrub at the impossible pedestal that has been written as "woman." The novel opens with the narrator already naked, and she remains so for the duration of the story. She has bared herself to the possibility of becoming her own heroine. By the end of the novel, the narrator has given birth to herself. 
"Now I'm out" the narrator declares, immediately after admitting: "No, that isn't right either" (171). Transforming memory into an exact signifier of events, is not the narrator's primary concern. Lying in the tub all day long, she begins to face the possibility of future. Just as "'woman' as signifier seems to show a remarkable stability: as site of change and changeability, innovation, rebirth, renewal, experiment and experimentation, the place for the planting of otherwise discredited questions" (Morris 66), so too does "woman" as signified express remarkable depth and texture, power and contradiction, subversion and reclamation. The narrator refers to her clit as "my widow's beak" (126) or "my dolorous reptile" (60) in coy imitation of the refusal to face directly or speak out loud a woman's sexual organs. Yet these inappropriate and unusual euphemisms point ironically to their literal counterparts, and to the difficulty a contemporary heroine faces when struggling to name or write her self.

In the bathroom, Scott's heroine must be flanked by mirrors, "that is, the gaze of others, the anticipated gaze of others" (Lenk 57, italics mine). She writes a construction of "self" against the previous constructions and versions of "heroine" by others. Upon first meeting Jon, she remembers he was "smiling at me through [his] round glasses" (9). His gaze and appraisal of her is equated with a reflection of herself that coincides in his glasses. And the aesthetics of how the two of them appear together - "we were a beautiful couple, everyone said so" (18) - grows out of her desire to fit or match her belief in his ideal of the perfect revolutionary woman, out of her desire to look the part.

The narrator feels scripted and conscripted into writing an account that others will value as legitimate. At the beginning of the novel, the narrator recalls overhearing a voice that declares, "she should adopt a more self-critical voice" $(10)$. Scott is grappling with the old idea that women are "too" subjective. Shortly after that, two lesbians singing their love in a telephone booth instruct the narrator on how to write her heroine (who is - and isn't - a heterosexual victim): "We hope the heroine of that story isn't a heterosexual victim. Il y en a trop dans le monde" (31). And Marie, who believes a feminist's responsibility is writing, demands: "How can a woman be centred if she isn't in charge of her words?" (59). The narrator, through her experience of this telling, is taking charge of and responsibility for - her words, and she achieves this by giving the words away. She divulges them to Sepia who is diary, self, lover, bath- 
tub, heroine, past lover, and ideal text. Sepia delineates the heroine's present, ongoing text. The narrator holds these words out to Marie, as replacement for more bodily offerings. She distorts them into surrealist poems. She writes them down. She speaks them out loud to herself as well as to the reader: "I'm telling stories" (10). That heroine who tradition consigns the role of either victim or bride, must be unwritten as part of the process of writing again. The narrator, washing herself in her bathtub, uncovers layers of herself that have been written over, identities she must uncover in order to discover. She bares her body to the mirror, to herself, to the text; she opens her pores to the experience of nakedness, revealed, retraced. A text to be rewritten. A text to rewrite.

"My desire was to create a new female subject-in-process through the act of writing - which act was also a process of deconstructing traditional fictions about women... But could a woman write without this dream, this imagining of a no longer muted feminine?" (Scott, Spaces Like Stairs, 62). Scott offers Heroine as solution to the "no longer muted feminine" voice. She steps out of the bathtub, "I'll just wrap myself up in the blanket and sit at that arborite table until dawn comes" (171), sits at the cheap motel table, and writes her words down. Earlier, she believed she needed a "smoother" (144) writing table. Now, she just sits down and writes. "The trick is to tell a story. Keeping things in the same time register" (31). By the end of the book the heroine exists as subject. Not just subject in a book, but as writer-is-subject because she actively writes: "she in fact offers herself, the writer, as an example of heroism: the literary heroine" (Irvine 119), and has only to surrender the words to paper to release herself as story; either happy or unhappy. "The rest of the time it's floating around in the middle enjoying the little consolations. The bath, the warmth, the television in the corner of the room. One thing about the Waikiki Tourist Rooms is they supply everything. A person doesn't have to worry. She can focus on her work" (41). The heroine who has spent the duration of the novel "floating around in" is the same heroine who has achieved a novel by the end of the book. The heroine has focused on her work. After the permanent separation from Jon, the narrator spends the day lying in the bath. After the earlier reconciliation, she had spent her time "lying on the rug in the dark red skirt, a white sweater, waiting for you my love" (172). Given the reconciliation that follows the first breakup, the "lying" she does on the rug is to herself. In the bath, the "lying" is for herself. 
In any narrative, "what happens next" ceases to be a pertinent question only at the conclusion, and the word "end" in a novel consequently carries with it not just the notion of the turnable last page, but also that of the "goal" of reading, the finish-line toward which our bookmarks aim (Torgovnick 3).

The convention of endings indicates a resolution of sorts; a tying together of events or ideas in order that the "questions" which propel the reader forward in the narrative stop demanding "answers" of the text.

The protagonist of Doris Lessing's, The Golden Notebook, draws thick black lines, sometimes doubled, at the "end" of each of her four notebooks. To indicate conclusion, because writing that continues on and on without structure is terrifying in its looseness and unpredictability.

[At this point Anna had drawn a heavy black line across the page. After it she had written:]

I drew that line because I didn't want to write it. As if writing about it sucks me even further into danger. Yet I have to hold fast to this - that Anna, the thinking Anna, can look at what Anna feels and 'name' it. (Lessing 479)

In Heroine, at the beginning of the first "chapter" after the momentous "ending" of the heroine's story, the narrator draws a thick black line and writes: "This is the line of pain. Like in Doris Lessing's (black) notebook" (173). So that the narrative that continues after this physical line is postclosure. Scott avoids ending by doubling it. If two endings follow immediately on the heels of the novel's closure, the structure of the novel challenges the necessity of that closure, exaggerating the literary convention of completion and ordered termination in order to undermine it. In resisting this notion of a final sentence as "finish-line," as "goal," Scott writes a narrative that desires to continue beginning, that has no belief in cessation or stasis.

A spiralling text does not demand the condition of completion that a circular ending proposes. The spiral is the doubled movement both away, and towards, the centre. Ever-widening, the spiral forms a cone that becomes the entire text, with the "middle" a small pin-point that takes up very little space. At the same time, the spiral turns inwards, the text writes itself closer and closer, yet never reaches or reveals that inner core. The technique of writing a spiral is Scott's process of narrative 
construction. And the narrator has the agency to choose. Not just one narrative direction over the other, but both or any, or all at the same time. "From that moment," the moment of the ending that is actually a beginning, "you know anything can happen" (172).

The narrator's ironical asides allow the text to acknowledge the either/or binary she desires to avoid. "A heroine locked in time could be the ruination of a novel. I should get out and write this down" (132). Her pivotal middle section allows her to flirt with the dangerous "The End" that looms as a goal for her - so far imaginary - words: "I got up to go, concentrating on how to put the whole symphony down on paper. With the heroine a free spirit (although you can taste the fragility of her chances, for self, for love) radiating from the middle of the story" (42). The heroine radiates out from the middle, but the beginning and the ending take up the bulk of the book, the most pages of her story.

Having successfully written herself out of the bathtub and onto the page, the narrator gives her heroine permission to do the same. And the book, then, comes to its "natural" conclusion. Scott's decision to push the narrative forward from this point writes against ending. The narrator, having figured out how to write herself, begins to do so. So the book ends without completion, but with the definite possibility of future.

So the narrative ends, dynamically. Or begins. Or middles. This potential future is a promise the narrator has made to herself: that getting out of the bathtub is possible and even desirable, and that the limits to her desires and their expression cannot be foreseen or defined. Her daydreams consist almost entirely of the past. Because the "bright hard edge of future" (159) slips away from her. Because recalling is the step that precedes recreating. Because the "future as an angle," (144) rather than a story-telling strategy, is what has been offered to Cassandra in Greek mythology. The narrator creates form as she articulates it. She calls this: "Going with the flow" (59). Of water, of words, of blood, of narrative, of desire, of anger, of displacement, of fulfillment, of ....

"Raising the issue of the future is another tactic for writing beyond the ending, especially as that ending has functioned in the classic novel: as closure of historical movement and therefore as the end of development" (DuPlessis 178). Scott introduces the future through her character's avoidance of its particularities. "Although she wants her heroine sensible of the 'edge of change,' pointed towards 'visions of the future' [94], the character persistently and nostalgically looks backward" 
(Irvine 117). Nevertheless, the two chapters that emerge after the "Orpheus waits" (172) can be both the (double-edged) return of Orpheus' wife Eurypides from Hades, or/and the bloody revenge of the Thracian women against Orpheus.

After the narrator draws "the line of pain" (173), the chapter "Jealousy, A Fish Story" begins with italicized diary entries. Like Lessing's A Golden Notebook, which is an amalgamation of the four separate notebooks and also the penultimate chapter of that book, this chapter has become the present actuality of what Scott's heroine is now able to transcribe onto paper. The chronological progression of the diary entries indicate a linearity that the novel preceding these two "final" chapters never maintained. As well, the heroine who has roused herself out of her memories in order to write, has now become writer - and editor-of her own text. The selection of material shapes the relationship between her and Jon into one of only jealousy or betrayal. If one were to read this chapter first, as an opening, the text focusing on only the failed love affair would deny the heroine's other layered selves.

"Play It Again, $\mathrm{S}^{\prime}$ tries for yet another tone, in yet another opening/final chapter. The italics have vanished, indicating a text that has moved out and beyond mere representation of the diary. The penultimate chapter is all diary, and the final chapter includes no diary entries whatsoever. Both lead (in circular spiral motion) to the text of Heroine, to the novel that the narrator is now able to begin.

The character, $\mathrm{S}$, is once again (and again and again) writing her self into the narrative. "Now I can keep the whole picture in my head" (179), she declares, then pushes the narrative back into "story," fictionalizing, rather than remembering. "The heroine raises her head from the arborite table" (179). This is after the point where the heroine has transcribed her diary entries. "Now they're at a distance" (180). This heroine has already learned to write her self and is about to venture out into the chaos of narrative in order to create a novel. "Elements for a novel. But first she needs to eat" (180). Now the heroine hears the grey woman's words. The grey woman who, until this point in the narrative, has not been heard (180). The distance of translating memory into text has opened her ears to new sounds and opened her body to new experiences. Memories are still interwoven into her narrative, but after each one, she manages to continue her movement by stepping forward or crossing a street. She reaches the point in the narrative where she can be startled by her own 
reflection in a window (183), and begins to recite a list of her thoughts and their various possibilities of expression. Again, Orpheus waits. But this time, the hero is a heroine, and the final paragraph, uncompleted, is one word.

That multifarious She- "is not only open-ended in terms of interpretation but insists that the reader continues to 'write'" (Blumberg 60). Heroine opens with imperatives and orders and closes with options and blank pages waiting to be filled. The novel's strategies of closure are multilayered offerings of openings and possibilities. That the book comes to an end (again and again and), does not limit the exploration of the text. The text, too, refuses limitation. Heroine: desire manifesto for its text as well as for its protagonist.

The narrator of Heroine is discovering how to perform Cixous' miracle to "write her self" (Cixous 875) as active subject into her own text. "I don't want a penis to decorate my body with. But I do desire the other for the other, whole and entire, male or female" (Cixous 891). The script for Heroine, then, will be written out of female desire. The heroine emerges victorious not because she has discovered and subsequently written an accurate account of her own experience, but through a recognition and expression of her desires. "Oh dream only a woman's mouth could do it as well as you" (9). In her opening, Scott positions the woman cheekily bathing while the world carries on around her, and she actively positions the tub and water as "lover," using the "white froth it's coming coming - please stay warm as a sperm river" (126) to replace not only the lover, Jon, who has denied himself to her, but also Marie whom she denies to herself. She is not merely masturbating; she constructs the faucet as an active participant, her outwardly moving desire, rather than let these versions of "lover" construct her as passive recipient.

Scott writes her character by writing that character's desire. "The aesthetic cannot be separated from the erotic" (Lenk 54). And she writes desire by constructing a space within which that character can safely desire, in order to get out of that confining space and desire in the open. The feminine aesthetic, then, demands the sensual and the erotic to metamorphose "woman" as signifier into "woman" as signified. Her sexual identity, except as scripted within the traditional heterosexual couple, has not yet been written enough for her to step into the role casually. Only as she begins to tell herself her own story, does she recognize this absence: "Oh Mama, why'd you put this hole in me?" (31). Later, she repeats this same phrase without the question mark. Her hole, her 
hungry mouth, her ever-tensing cunt is her constructed aesthetic, her poetic process, the expectation of longing she begins to write against. Scott writes her heroine surrounded and encased by the enamel tub. She constructs the city outside her window not just from the narrator's limited view of it, but with the voice inside the radio that gives broadcasts about the FLQ kidnapping of "ten years ago this month" (13). The tourist (having been allowed to lose the adjective), roams past the hookers, across conversations in the cafes, down Rue Ste. Catherine, beyond the line of the narrator's vision. Whose desire to write this novel splashes out of the tub long before she does - her words precede her. "The city. Hot autumn. In an apartment a couple are sitting at a table discussing revolution" (49). The perfect couple, reflecting their prescripted lives together. Scott reaches in and reverses the mirror: "the narrator tries stepping through. Alice's looking glass in order to discover a new angle" (Irvine 118). This process does not dismiss the traditional role of womanas-object-of-desire, but rather establishes the stronger role of objectdesiring, so that the heroine can invent herself as subject-in-process. An invention that subverts the notion that female desire (when recognized as existing at all) must declare its limits. Through this technique of "tactical reversal and resistance, women are turning their sex-saturation back on the sexuality apparatus (sex you have said we are, sex we will be...) and in doing so, women begin to outflank it" (Morris 67-8).

Heroine is a discourse of desire; a breakup of prescripted longings. The traditional love story implies bookends (two lovers holding up the "middle"): a beginning and an end. But the story of a woman desiring, an ongoing story still being written, is open-ended and cannot rely on a plot-oriented middle culminating in the conventional climaxed version of closure. The heroine of this novel doesn't want the pleasure of desire to come to an end (just one more, then I'll get out, just one more); she desires the freedom to desire, to pursue her aureoled cravings along whichever literary paths she pleases.

Sepia, she's so beautiful when she talks of writing, you can almost feel the edge of freedom. As in a Cocteau film, ca 1940. A woman in a black skirt, black gloves, nipped in waist is walking out a door towards a black and white cafe. Orpheus waits. From that moment, you know anything can happen (172).

The narrator envisions herself to be Marie, walking calm and confident toward her destination. The desire she expresses is not just 
sexual, but a desire to be her whole self. A desire to write, to speak of writing in a way that engages further desire. A desire for the "edge" of freedom. A desire for visual aesthetics. A desire for desire. Because it is not what the heroine desires, but that she desires. No limit in sight.

\section{Works Cited}

Blumberg, Marcia. "Rereading Gail Scott's Heroine: a Triple Lens of Sighting/Citing/Siting." Open Letter, 8.2 (Winter 1992): 57-69. Cixous, Helene. "The Laugh of the Medusa." Signs: Journal of Women in Culture and Society. 1 (1976): 875- 93.

DuPlessis, Rachel Blau. Writing Beyond the Ending: Narrative Strategies of Twentieth-Century Women Writers. Bloomington: Indiana University Press, 1985.

Irvine, Lorna. "Words on the Prowl: Quebec Literature and Gail Scott's Heroine." Quebec Studies 9 (1989/90): 111-120.

Lenk, Elizabeth. "The Self-reflecting Woman." Feminist Aesthetics, ed. Gisela Ecker, trans. Harriet Anderson. London: The Women's Press Ltd. (1985): 51-58.

Lessing, Doris. The Golden Notebook. New York: Ballantine Books, 1962. Munro, Alice. Lives of Girls and Women. Ontario: McGraw- Hill Ryerson Ltd., 1971.

Morris, Meaghan. The Pirate's Fiancee: Feminism, reading, postmodernism. London: Verso, 1988.

Scott, Gail. Heroine. Toronto: Coach House Press, 1987.

—. Spaces Like Stairs. Toronto: The Women's Press, 1989.

Thomas, Audrey. Latakia. Vancouver: Talonbooks, 1979.

Torgovnick, Marianna. Closure in the Novel. Princeton: Princeton University Press, 1981. 